\title{
The Hypnotic, Anxiolytic, and Antinociceptive Profile of a Novel $\mu$-Opioid Agonist
}

\author{
Guilherme Carneiro Montes ${ }^{1}$, Bianca Nascimento Monteiro da Silva ${ }^{2}$, Bismarck Rezende ${ }^{1}$, \\ Roberto Takashi Sudo 1,3, Vitor Francisco Ferreira ${ }^{4}$, Fernando de Carvalho da Silva ${ }^{4}$, \\ Angelo da Cunha Pinto ${ }^{2,3}$, Bárbara Vasconcellos da Silva ${ }^{2}$ and Gisele Zapata-Sudo 1,3,* \\ 1 Programa de Pesquisa em Desenvolvimento de Fármacos, Instituto de Ciências Biomédicas, \\ Universidade Federal do Rio de Janeiro, Rio de Janeiro RJ 21941-902, Brazil; \\ montes.guilherme@gmail.com (G.C.M.); bismarckrezende@gmail.com (B.R.); \\ rtakashisudo@gmail.com (R.T.S.) \\ 2 Instituto de Química, Universidade Federal do Rio de Janeiro, Rio de Janeiro RJ 21941-909, Brazil; \\ bianca_qnascimento@yahoo.com.br (B.N.M.d.S.); angelocpinto@gmail.com (A.d.C.P.); \\ barbara.iq@gmail.com (B.V.d.S.) \\ 3 Instituto Nacional de Ciência e Tecnologia de Fármacos e Medicamentos (INCT-INOFAR), \\ Rio de Janeiro RJ 21941-971, Brazil \\ 4 Instituto de Química, Universidade Federal Fluminense, Niterói RJ 24020-150, Brazil; \\ cegvito@vm.uff.br (V.F.F.); gqofernando@vm.uff.br (F.d.C.d.S.) \\ * Correspondence: gzsudo@oi.com.br; Tel./Fax: +55-21-3938-6505
}

Academic Editor: Derek J. McPhee

Received: 10 March 2017; Accepted: 26 April 2017; Published: 16 May 2017

\begin{abstract}
Alkyl/aryl-1H-1,2,3-triazole derivatives PILAB 1-12 were synthesized and a pharmacological screening of these derivatives was performed to identify a possible effect on the Central Nervous System (CNS) and to explore the associated mechanisms of action. The mice received a peritoneal injection $(100 \mu \mathrm{mol} / \mathrm{kg})$ of each of the 12 PILAB derivatives $10 \mathrm{~min}$ prior to the injection of pentobarbital and the mean hypnosis times were recorded. The mean hypnosis time increased for the mice treated with PILAB 8, which was prevented when mice were administered CTOP, a $\mu$-opioid antagonist. Locomotor and motor activities were not affected by PILAB 8. The anxiolytic effect of PILAB 8 was evaluated next in an elevated-plus maze apparatus. PILAB 8 and midazolam increased a percentage of entries and spent time in the open arms of the apparatus compared with the control group. Conversely, a decrease in the percentages of entries and time spent in the closed arms were observed. Pretreatment with naloxone, a non-specific opioid antagonist, prior to administration of PILAB 8 exhibited a reverted anxiolytic effect. PILAB 8 exhibited antinociceptive activity in the hot plate test, and reduced reactivity to formalin in the neurogenic and the inflammatory phases. These data suggest that PILAB 8 can activate $\mu$-opioid receptors to provoke antinociceptive and anti-inflammatory effects in mice.
\end{abstract}

Keywords: novel $\mu$-opioid agonist; hypnosis; antinociception; anti-inflammatory effect; mice

\section{Introduction}

Pain is defined as an unpleasant sensory feeling that results from activation of sensory nerve endings in response to a stimulus which can vary among individuals due to emotional state, gender, ethnicity, anxiety level, early experiences and memories [1-6]. Pain management to improve quality of life depends on agents with analgesic properties such as non-narcotic analgesics (e.g., acetominophen and aspirin), narcotic analgesics (opioids), and other drug classes, including antidepressants and anticonvulsants $[7,8]$. However, reduction of pain is limited, which is the main 
reason for the development of new therapies [9]. Isatin ( $1 H$-indole-2,3-dione, 1, Figure 1$)$, is distributed among various regions of the brain and heart, thereby indicating that this substance has important physiological functions. Isatin and its derivatives act by inhibiting the enzyme monoamine oxidase $\mathrm{B}$ (MAO-B) in the brain and reducing the formation of cyclic guanosine monophosphate (cGMP). In addition, isatin interacts with benzodiazepine receptors such as the ligand-gated ion channel receptor $\gamma$-aminobutyric acid (GABA), which can mediate sedative, hypnotic, analgesic, and other important effects on the central nervous system (CNS) [10-13]. Several studies have demonstrated that isatin derivatives could promote actions on the CNS. Thus, compound 2 (Figure 1) was described as anticonvulsant agent [14], compounds 3 and 4 (Figure 1) inhibited human GABA transporter 3 [15] and compound 5 (Figure 1) produced a positive allosteric modulation of human muscarinic M1 receptor [16].

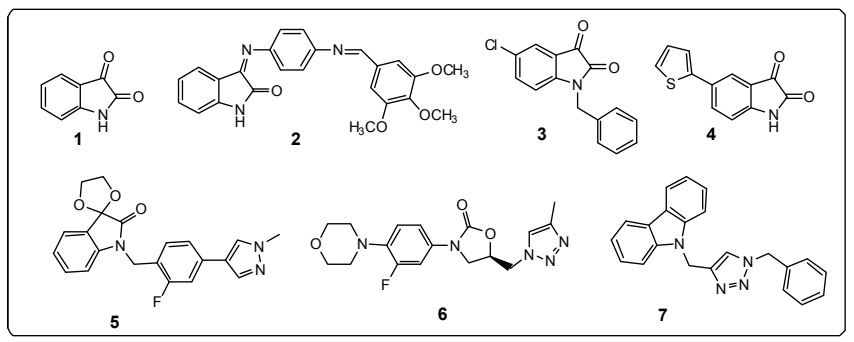

Figure 1. Structure of isatins 1-5 and triazoles derivatives 6-7.

Triazoles containing oxazolidinone rings mediate inhibition of $\mathrm{MAO}$ and the presence of the methyl group on the triazolic ring (e.g., compound 6, Figure 1) provides selectivity for the MAO-B isoform [17]. Carbazole derivatives containing the N-benzyl-1,2,3-triazole moiety like 7 (Figure 1) also exhibit significant anti-acetylcholinesterase activity $\left(\mathrm{IC}_{50} \leq 3.8 \mu \mathrm{M}\right)$. Meanwhile, molecular modeling studies have shown the existence of $\pi-\pi$ interactions between the triazole ring and Tyr334 in the anionic binding site of the enzyme [18].

Previously, we reported that dioxolane ketal isatin derivatives such as 8 (Figure 2) exhibited beneficial effects on sleep disorders and represented an alternative for the maintenance of anesthesia [19]. Fix figure: R1 and R4 are electron donating or withdrawing groups; there is no $\mathrm{R}^{\prime \prime}$ in the Figures.

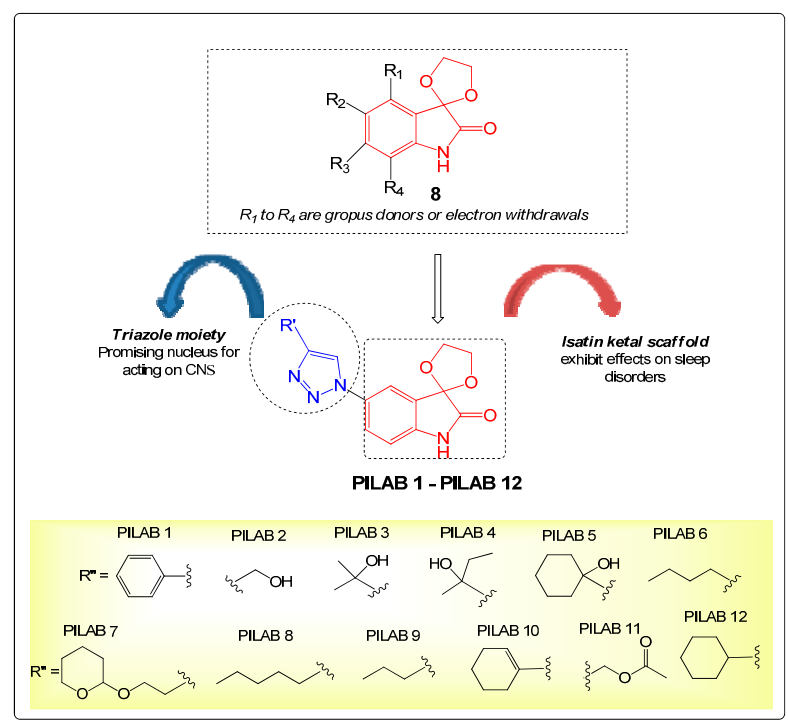

Figure 2. Design of isatin-triazoles PILAB 1-PILAB 12 with potential CNS activity, and structure of dioxolane ketal isatin derivatives 8 previously evaluated by our research group. 
The compounds were initially synthesized using a 1,3-dipolar cycloaddition reaction catalyzed by acetic acid [20] and then, the route was improved using ultrasound irradiation, which reduced the reaction time to $5 \mathrm{~min}$, with no need of purification using column chromatography [21]. Thus, the present work reports the action of isatin-type 5'-4-akyl/aryl-1H-1,2,3-triazoles PILAB 1-PILAB 12 on the CNS through the evaluation of their sedative-hypnotic profile. The compound with optimal activity was selected and further evaluated to elucidate the mechanisms involved in its action.

\section{Results}

\subsection{Effect of PILABs on Pentobarbital-Induced Sleep}

As illustrated in Figure 3, the duration of pentobarbital-induced sleep increased from $30.0 \pm 2.2 \mathrm{~s}$ in the animals that received vehicle to $75.1 \pm 9.9 \mathrm{~s}, 105.4 \pm 7.8 \mathrm{~s}, 67.2 \pm 7.7 \mathrm{~s}, 114.6 \pm 11.8 \mathrm{~s}, 86.6 \pm 5.7 \mathrm{~s}$, $65.3 \pm 6.8 s$ and $66.8 \pm 11.4 s$ when the mice were treated with PILAB 4, 6, 7, 8, 9, 11 and 12, respectively.

\begin{tabular}{|c|c|c|c|c|c|}
\hline$\square$ & vehicle & 己 & PILAB 3 & 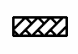 & PILAB 8 \\
\hline & azide & पा & PILAB 4 & $\nabla \nabla$ & PILAB 9 \\
\hline$\cdots$ & isatin & एवय & PILAB 5 & $\mathbb{Z}$ & PILAB \\
\hline $\mathrm{B}$ & PILAB 1 & पाण & PILAB 6 & 00 & PILA \\
\hline$\square$ & PILAB 2 & 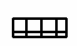 & PILAB 7 & & गILA \\
\hline
\end{tabular}

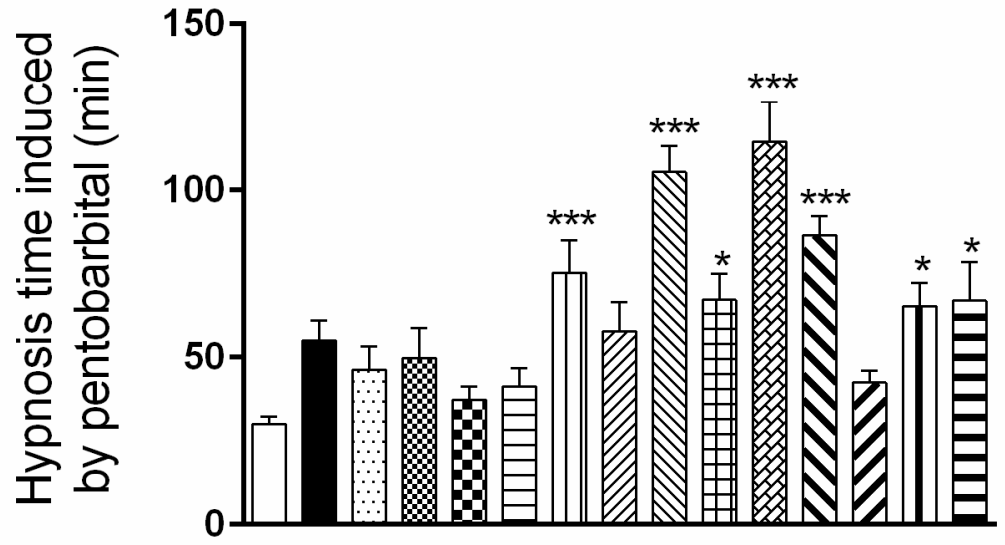

Figure 3. Effect of PILABs $(100 \mu \mathrm{mol} / \mathrm{kg})$ on the duration of pentobarbital-induced sleep. Mice received i.p. injections of the PILABs indicated $30 \mathrm{~min}$ prior to an i.v. injection of sodium pentobarbital $(20 \mathrm{mg} / \mathrm{kg}$ ). Hypnosis time was recorded based on the loss and recovery of the righting reflex. Data are expressed as the mean $\pm \operatorname{SEM}(n=10) .{ }^{*} p<0.05$, and ${ }^{* * *} p<0.001$ compared to the vehicle-treated group, one-way ANOVA followed by Dunnett's multiple comparison test for parametric measures.

\subsection{Hypnosis Following i.v. Injections of the Various PILABs and an Evaluation of the Mechanism of Action}

PILAB 4, 6, 7, 8, 9, 11 and 12 were selected for testing if they alone could induce hypnosis after intravenous injection. PILAB 6 and PILAB 8 enhanced the hypnosis time from $12.2 \pm 6.3 \mathrm{~s}$ (vehicle) to $127.8 \pm 31.7 \mathrm{~s}$ and $260.0 \pm 58.9 \mathrm{~s}$, respectively (Figure 4). 


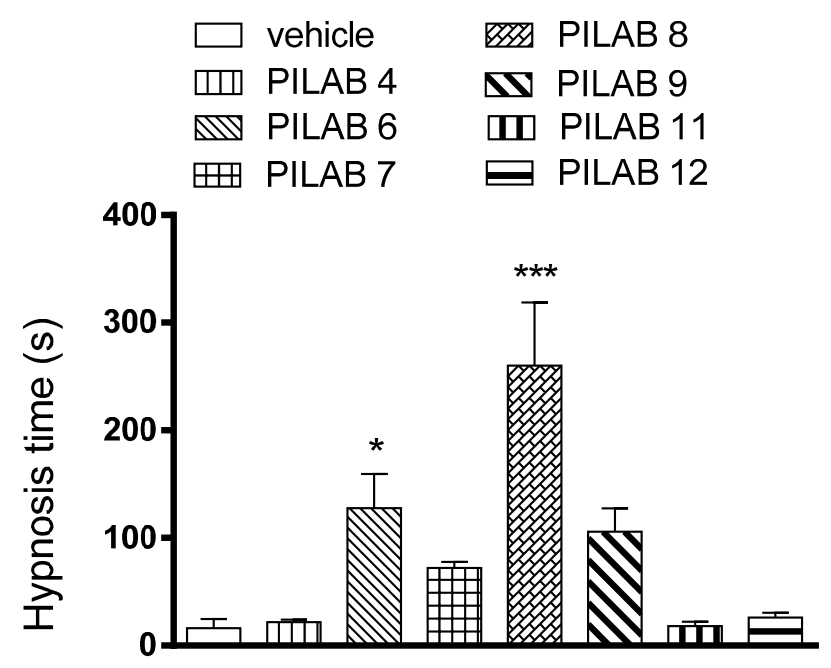

Figure 4. Hypnosis time following i.v. administration of the PILABs $(100 \mu \mathrm{mol} / \mathrm{kg})$. Time intervals between loss and recovery of righting reflex were recorded. Data are expressed as the mean \pm SEM $(n=10) .{ }^{*} p<0.05$ and ${ }^{* * *} p<0.001$ compared to the vehicle-treated group, one-way ANOVA followed by Dunnett's multiple comparison test for parametric measures.

PILAB 8 promoted hypnosis in a dose dependent manner because when it was administered at doses of $150 \mu \mathrm{mol} / \mathrm{kg}$ and $300 \mu \mathrm{mol} / \mathrm{kg}$, a further increase in hypnosis time was observed $(439.8 \pm 82.7 \mathrm{~s}$ and $1017.0 \pm 313.0 \mathrm{~s}$, respectively (Figure 5).

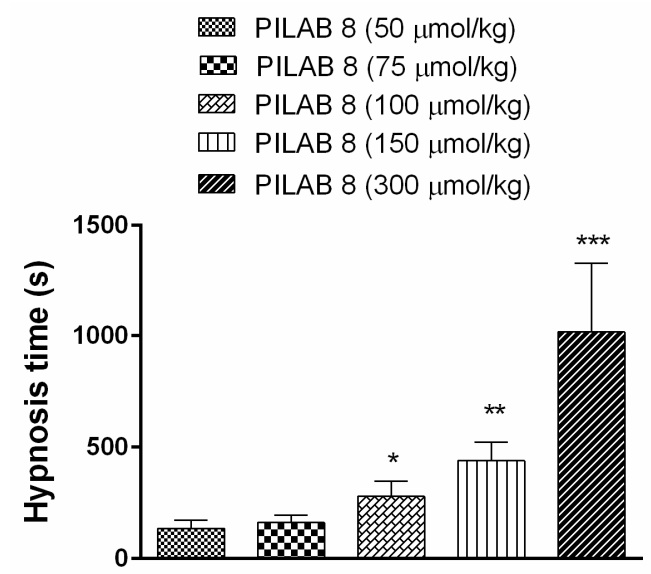

Figure 5. Hypnosis time following the i.v. administration of varying doses of PILAB 8. Time intervals between loss and recovery of the righting reflex were recorded. Data are expressed as the mean \pm SEM $(n=6) .{ }^{*} p<0.05$ and $^{* *} p<0.01$ and ${ }^{* * *} p<0.001$ compared to PILAB $8(50 \mu \mathrm{mol} / \mathrm{kg})$, one-way ANOVA followed by Student's unpaired $t$-test.

To evaluate the mechanism mediating the observed increase in hypnosis time following administration of PILAB 8, mice were pre-treated with naloxone and other specific opioid pathway antagonists. The hypnosis time associated with naxolone decreased to $55.7 \pm 14.3 \mathrm{~s}$, while the administration of naltrindole, nor-binaltorphimine, and CTOP reduced the hypnosis times to $156.1 \pm 37.0 \mathrm{~s}, 142.6 \pm 45.1 \mathrm{~s}$ and $10.6 \pm 2.8 \mathrm{~s}$, respectively (Figure 6). 

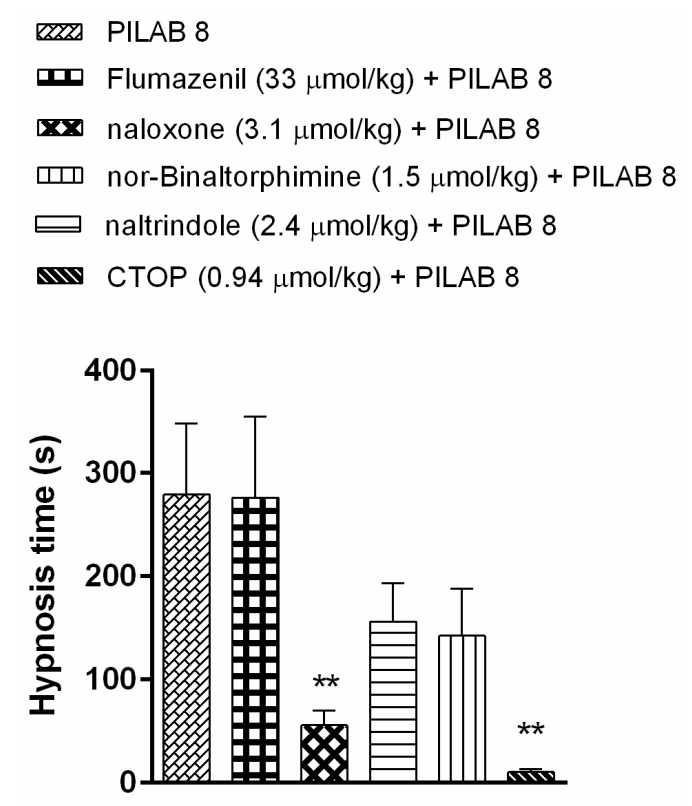

Figure 6. Effects of PILAB $8(100 \mu \mathrm{mol} / \mathrm{kg})$ on hypnosis time following pre-treatment with flumazenil (33 $\mu \mathrm{mol} / \mathrm{kg})$, naloxone $(3.1 \mu \mathrm{mol} / \mathrm{kg})$, nor-binaltorphimine $(1.5 \mu \mathrm{mol} / \mathrm{kg})$, naltrindole $(2.4 \mu \mathrm{mol} / \mathrm{kg})$, or CTOP $(0.94 \mu \mathrm{mol} / \mathrm{kg})$. Time intervals between loss and recovery of the righting reflex were recorded. Data are expressed as the mean $\pm \operatorname{SEM}(n=10)$. ${ }^{* *} p<0.01$ compared to PILAB $8(100 \mu \mathrm{mol} / \mathrm{kg}$ i.v. $)$, one-way ANOVA followed by Dunnett's multiple comparison test for parametric measures

\subsection{Effect of PILAB 8 on Locomotor Activity and Performance in the Moto Coordination (Rotarod Test)}

None significant impairment in motor activity was detected following an i.p. injection of PILAB 8 $(25 \mu \mathrm{mol} / \mathrm{kg})$ in the rotarod test compared with the mice that received an i.p. injection of vehicle (Figure 7).

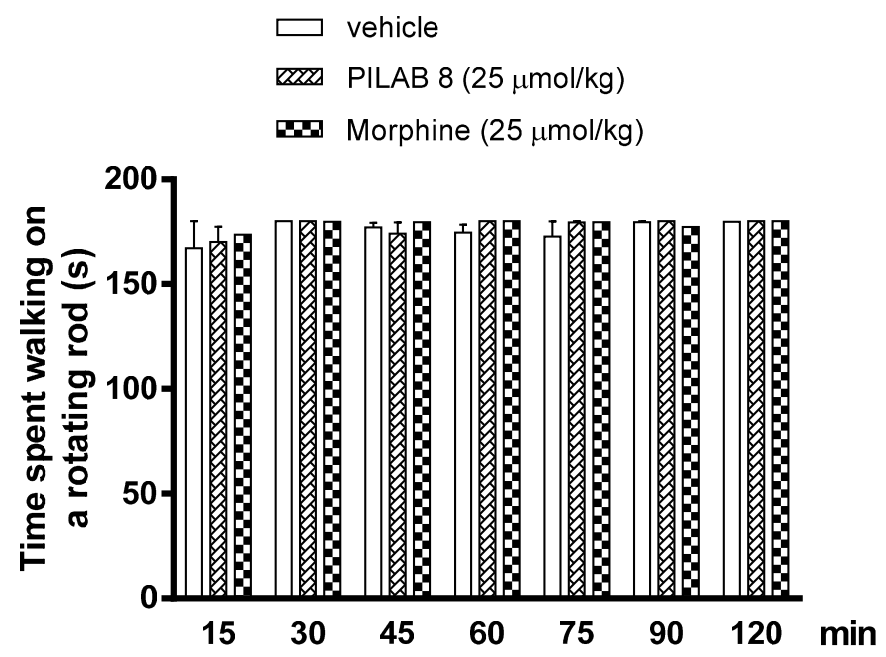

Figure 7. Effects of vehicle versus PILAB 8 on motor coordination. Mice received an i.p. injection of vehicle or PILAB $8(100 \mu \mathrm{mol} / \mathrm{kg})$ and then underwent a rotarod test $15,30,45,60,75,90$, and $120 \mathrm{~min}$ later. Data are expressed as the mean time spent walking on the rotating rod $\pm \operatorname{SEM}(n=10)$ and were analyzed with the Kruskal-Wallis test followed by Dunnett's multiple comparison test for parametric measures. 


\subsection{Effect of PILAB 8 on the Anxiolytic Response}

Figure 8 shows the percentage of the number of entries into the open and closed arms on the EPM by the various groups. The percentage of entries into the open arms by the mice that were treated with PILAB 8 and midazolam increased from $32 \pm 4 \%$ (value for the control group treated with vehicle) to $64 \pm 11 \%$ and $65 \pm 7 \%$, respectively. For entries into the closed arms, the percentage values decreased from $66 \pm 5$ (for the control group treated with vehicle) to $35 \pm 11 \%$ and $34 \pm 7 \%$ respectively.

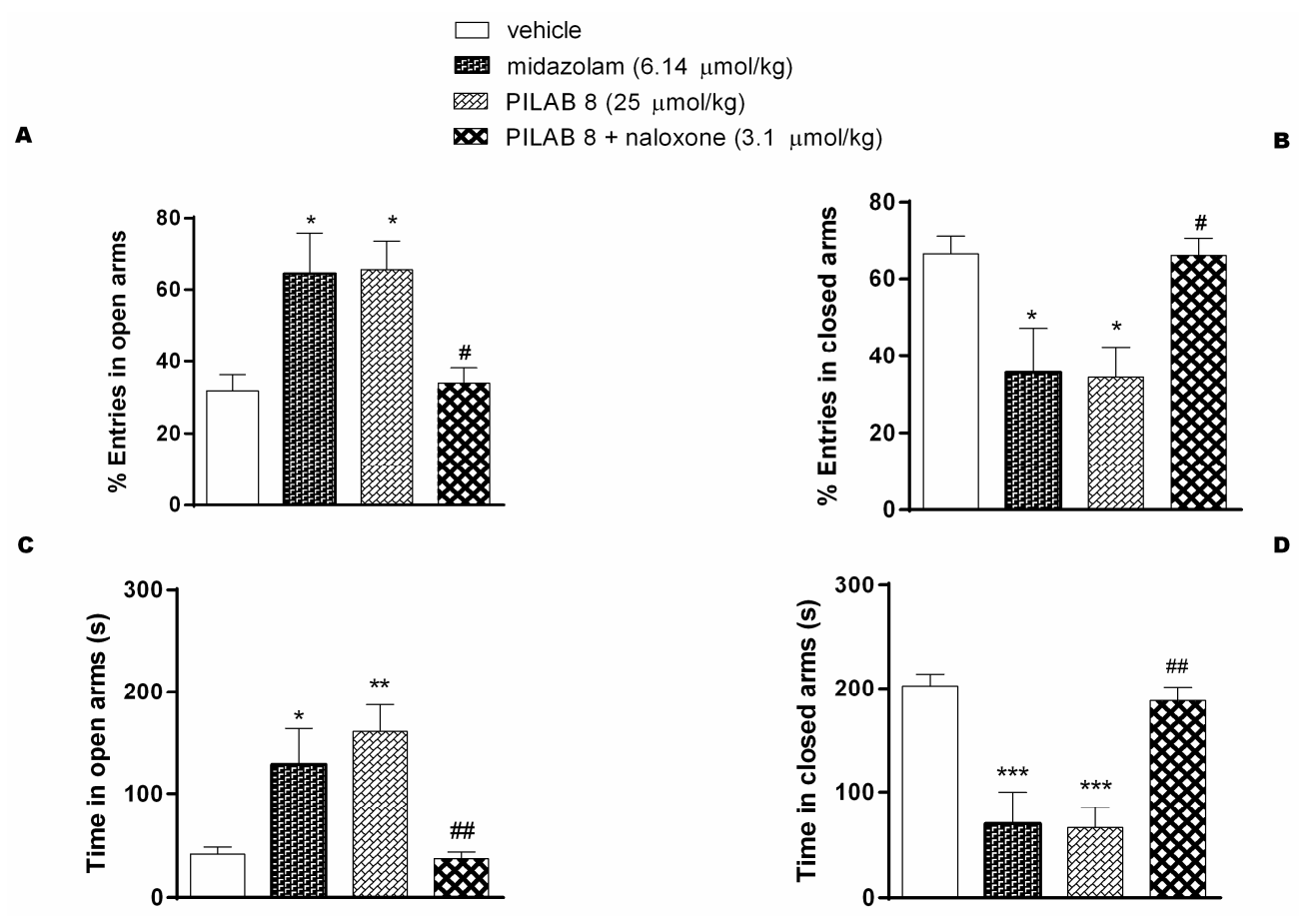

Figure 8. Effects of PILAB $8(25 \mu \mathrm{mol} / \mathrm{kg})$ or midazolam $(6.15 \mu \mathrm{mol} / \mathrm{kg})$ with or without prior administration of naloxone $(3.1 \mu \mathrm{mol} / \mathrm{kg})$. The percentage of entries into the open arms $(\mathbf{A})$ and the closed arms (B) of the EPM over a 5 min interval are presented. ${ }^{*} p<0.05,{ }^{* *} p<0.01$, and ${ }^{* * *} p<0.001$ vs. vehicle; ${ }^{\# \#} p<0.01$ vs. PILAB 8. The time spent in the open arms (C) and the closed arms (D) of the EPM over a 5 min interval. ${ }^{*} p<0.05,{ }^{* *} p<0.01$ and ${ }^{* * *} p<0.001$ vs. vehicle; ${ }^{*} p<0.05,{ }^{\# \#} p<0.01$ vs. PILAB 8.

Treatment with PILAB 8 and midazolam also increased the time spent in the open arms from $41.3 \pm 6 \mathrm{~s}$ (vehicle group) to $161 \pm 26 \mathrm{~s}$ and $129 \pm 35 \mathrm{~s}$, respectively. Conversely, the time spent in the closed arms decreased from $203 \pm 11 \mathrm{~s}$ to $66 \pm 19 \mathrm{~s}$ and $70 \pm 30 \mathrm{~s}$, respectively. When the mice were pre-treated with naloxone and then were treated with PILAB 8, the percentages for open and closed arm entries were $34 \pm 4 \%$ and $66 \pm 4 \%$, respectively. The time spent in the open and closed arms were $37 \pm 7 \mathrm{~s}$ and $188 \pm 13 \mathrm{~s}$, respectively.

\subsection{Effect of PILAB 8 on Formalin-Induced Nociception Response}

An i.pl. injection of formalin $(20 \mu \mathrm{L})$ was performed to provoke a classical nociceptive response (time of flinching, lifting, licking, shaking, biting behavior) in two phases. In the neurogenic phase, mice that were administered PILAB 8 or morphine exhibited reduced formalin responsiveness from $44 \pm 6 \mathrm{~s}$ (for the vehicle group) to $21 \pm 5 \mathrm{~s}$ and $8 \pm 4 \mathrm{~s}$, respectively. In contrast, administration of acetylsalicylic acid did not attenuate formalin responsivity. In the inflammatory phase, the animals treated with PILAB 8, morphine, or acetylsalicylic acid all exhibited a decrease in formalin responsiveness from $231 \pm 54 \mathrm{~s}$ (for the vehicle group) to $40 \pm 17 \mathrm{~s}, 10 \pm 6 \mathrm{~s}$ and $93 \pm 19 \mathrm{~s}$, respectively (Figure 9). 


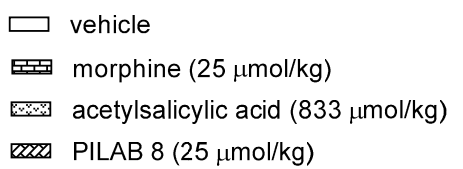

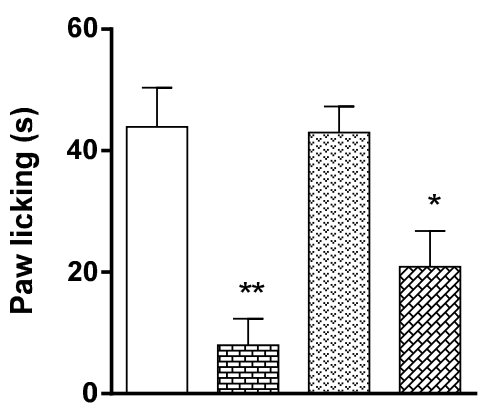

Phase I

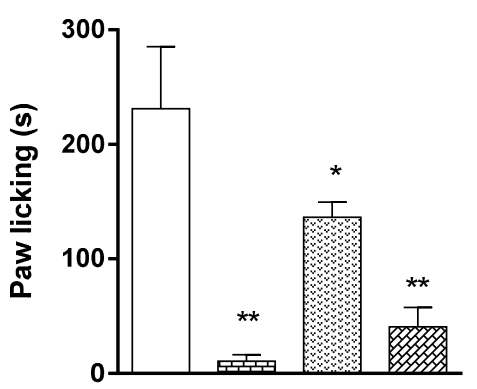

Phase II

Figure 9. Evaluation of the antinociceptive activity of PILAB $8(25 \mu \mathrm{mol} / \mathrm{kg}$ i.p.), morphine $(25 \mu \mathrm{mol} / \mathrm{kg}$ i.p.) and acetylsalicylic acid $(833 \mu \mathrm{mol} / \mathrm{kg}$ i.p.) in the formalin test. Intraperitoneal injections each substance were performed $30 \mathrm{~min}$ prior to the injection of formalin and subsequently observed during $30 \mathrm{~min}$. Data are expressed as the mean time of reactivity (time spent licking) \pm SEM $(n=10) .{ }^{*} p<0.05$ and ${ }^{* *} p<0.01$ vs vehicle-treated group, one-way ANOVA followed by Dunnett's test.

\subsection{Effect of PILAB 8 on Hot Plate-Induced Nociception Response}

When mice received an i.p. injection of PILAB $8(25 \mu \mathrm{mol} / \mathrm{kg})$ prior to a hot plate test, the mice exhibited a antinociceptive activity percentage of $(38 \pm 8 \%) 70 \mathrm{~min}$ later. Compared with the animals that received vehicle $(6 \pm 3 \%)$, this increase in latency response to thermal stimuli was significant.

Possible involvement of the opioid system in mediating the antinociceptive effect of PILAB 8 was subsequently examined. When mice were pre-treated with naloxone $(3.1 \mu \mathrm{mol} / \mathrm{kg}$, i.p.) for $15 \mathrm{~min}$ prior to an i.p. injection of PILAB 8, antinociception was significantly reduced to $12 \pm 5 \%$ at the $70 \mathrm{~min}$ time point for the hot plate test (Figure 10).

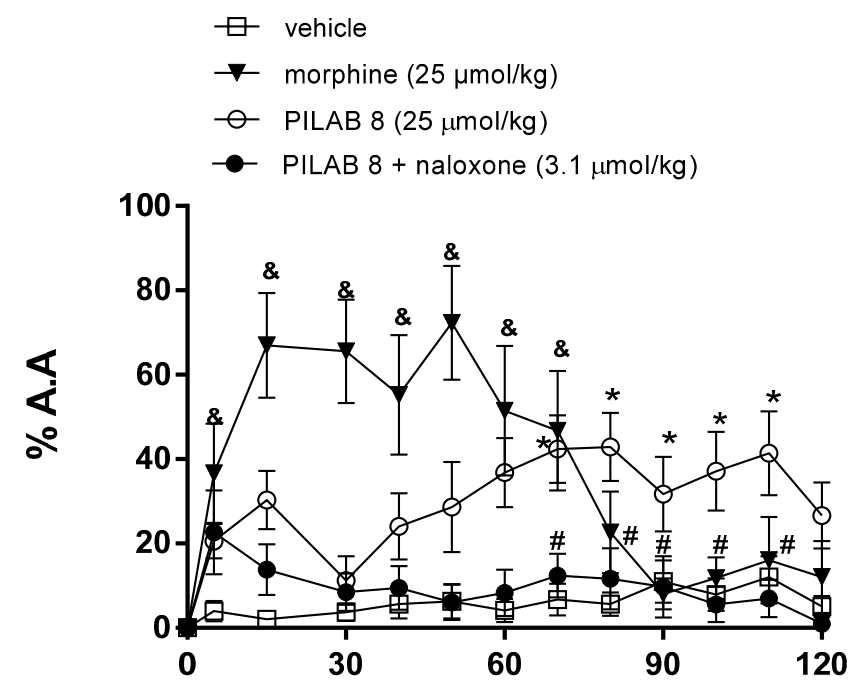

Figure 10. Effects of the intraperitoneal injection of vehicle, PILAB $8(25 \mu \mathrm{mol} / \mathrm{kg})$, morphine $(25 \mu \mathrm{mol} / \mathrm{kg})$ and pretreatment with naloxone $(3,1 \mu \mathrm{mol} / \mathrm{kg})$ in animals received PILAB 8 (i.p.) in a hot plate test. Data are expressed as the mean \pm SEM $(n=8-10)$. ${ }^{*} p<0.05$ and $\& p<0.05$ vs. vehicle; \# $p<0.05$ vs. PILAB 8, one-way ANOVA followed by Dunnett's test. 


\section{Discussion}

Various isatin-type 5'-4-alkyl/aryl-1H-1,2,3-triazoles PILAB 1-12 were initially evaluated in the pentobarbital-induced sleep assay. All of the isatin-triazole derivatives significantly increased the duration of hypnosis. PILAB 6, PILAB 8 and PILAB 9 were particularly effective, and all of these contain a linear alkyl chain linked to the triazole ring. These results suggest that the apolar portion present in the triazole plays a key role in facilitating the movement of this compound across the blood brain barrier. Moreover, after an i.v. injection of PILAB 8, a hypnotic-like profile approximately 3 times greater than that achieved with PILAB 6 and PILAB 7 was observed. Compound PILAB 9, containing a propyl group attached to the triazole ring, also induced a hypnotic-like profile, although it was not greater than the hypnotic profiles of PILAB $6\left(R^{\prime}=\right.$ butyl) and PILAB $8\left(R^{\prime}=\right.$ pentyl). Those results indicated that the size of the alkyl chain is an important factor to the modulation of the activity. In contrast, compounds PILAB 1 and PILAB 10, containing a phenyl and cyclohex-1-en-1-yl group, respectively, did not produce important effects. Similar results were observed with polar compounds like PILAB 2 ( $\mathrm{R}^{\prime}$ = hydroxymethyl), PILAB 3 ( $\mathrm{R}^{\prime}$ = 2-hydroxy-propan-2-yl) and PILAB 5 ( $\mathrm{R}^{\prime}=$ 1-hydroxycyclohexyl).

The hypnotic profile of PILAB 8 was of particular interest and subsequent pretreatment experiments with the non-selective opioid antagonist, naloxone, and the $\mu$-opioid selective antagonist, CTOP, were found to prevent the hypnosis induced by PILAB 8.

It is hypothesized that PILAB 8 could bind and activate the $\mu$-opioid receptor, which represents a coupled Gi protein. To date, agonist $\mu$-opioid receptors induce analgesia for relief of some of the most chronic types of pain. However, activation of these receptors may produce adverse effects such as respiratory depression, sedation, addiction, and tolerance, and these side effects limit their clinical use [22].

In the present study, when PILAB 8 was administered at a dose of $25 \mu \mathrm{mol} / \mathrm{kg}$ via an i.p. injection, neither sedation nor locomotor activity alterations were observed. Intraperitoneal administration of PILAB 8 did not result in locomotor activity changes, ensuring continuity for assessments of other behavioral assessments since changes might reduce the behavioral response, thereby resulting in a false positive effect.

The anxiolytic profile of PILAB $8(25 \mu \mathrm{mol} / \mathrm{kg}$, i.p.) was examined with an EPM test to investigate both physiological and pharmacological behavior [23]. When animals are less anxious they tend to enter the open arms of the device and stay there longer. Meanwhile, an anxiogenic substance produces the opposite effects [24-28]. The opioid pathway plays an important role in the modulation of anxiety, and activation of this pathway has been hypothesized to mediate anxiolytic responses [29]. For example, when the $\mu$-opioid receptor agonist, endomorphine 1 , was administered intracerebroventricularly into mice, an anxiolytic effect was observed in the EPM test [29-32]. Based on these findings and the results of the EPM assays conducted in the present study, it appears that the anxiolytic effect of PILAB 8 is mediated via $\mu$-opioid receptors.

Injection of formalin induced initially a neurogenic phase followed by a inflammatory-induced pain [33-36]. The early phase is consequent to a stimulation of nociceptors, activation of C-fiber afferents which resulted in increased release of glutamate and aspartate into the dorsal horn [34,37,38]. The late phase is due to a local inflammatory reaction, which promotes the release of prostaglandins, bradykinin, serotonin and histamine [34,39]. Generally, drugs such as opioids inhibit both phases of the formalin test [40] However, the peripheral action of drugs such as non-narcotic agents have been observed to improve the nociceptive response to formalin in the second phase, while the initial antinociception phase remains unaffected [34]. Our results demonstrated that PILAB 8 inhibited both phases of the formalin-induced nociception test, thus a noxious thermal stimulus induced by a hot plate was used to investigate the analgesic drug action [33,41]. At a dose of $25 \mu \mathrm{mol} / \mathrm{kg}$, PILAB 8 increased the percentage of the antinociceptive response and this response reverted when the mice were pretreated with naloxone, an opioid antagonist. In the present study, PILAB 8 exhibited antinociceptive action. It was previously reported that a subset of isatin analogs exhibit antinociceptive effects in both 
chemical and thermal models of nociception, and the mechanism of action may involve the opioid pathway [42]. Primary afferent nociceptive fibers express $\mu$-opioid receptors, and the majority of these receptors are localized to the periphery of the fibers. Moreover, activation of these $\mu$-opioid receptors has been hypothesized to produce antinociceptive effect [43-45]. It is hypothesized that PILAB 8, a $\mu$-opioid agonist, may provide beneficial effects in animal models of pain activating the opioid system to induce an antinociception mechanism.

\section{Material and Methods}

\subsection{Synthesis of Hybrid Triazole-Isatin Derivatives}

Derivatives of $5^{\prime}$-(4-akyl/aryl-1H-1,2,3-triazole)-isatin were obtained by treating 5-azido-spiro[1,3dioxolane-2,3'-indol]-2' $\left(1^{\prime} H\right)$-one with various alkynes under acidic conditions followed by the application of ultrasound irradiation as described by Silva et al. [20,21]. The twelve $5^{\prime}$-(4-akyl/aryl1H-1,2,3-triazole)-isatin derivatives PILAB 1-12, as well as the precursors, isatin and 5-azido-spiro[1,3dioxolane-2,3'-indol]-2' $\left(1^{\prime} H\right)$-one (1), were evaluated for hypnotic-sedative activity (Table S1).

\subsection{Analysis of the Purity of the Compounds Evaluated by HPLC (High Performance Liquid Chromatography)}

The HPLC analysis was conducted on a Shimadzu LC20AT system (Shimadzu, Kyoto, Japan). The Shimadzu Lab solutions software was used for data acquisition. Acetonitrile/methanol $(5: 95 \mathrm{v} / \mathrm{v})$ was used as the mobile phase with a $150 \times 4.6-\mathrm{mm}$ Eclipse Plus C18 column. The flow rate was $1 \mathrm{~mL} / \mathrm{min}$ and the injection volume was $1 \mu \mathrm{L}$. The wavelength of detection used was $280 \mathrm{~nm}$. The purities of the compounds are shown in Table S2.

\subsection{Animals}

The experimental protocols used in the present study were approved by the Animal Care and Use Committee of the Universidade Federal do Rio de Janeiro, Brazil (CEUA/UFRJ DFBCICB068). Briefly, male Swiss mice (25-35 g) were kept in polypropylene boxes containing sawdust and were maintained under controlled temperature $\left(21 \pm 1{ }^{\circ} \mathrm{C}\right)$ and humidity $(60 \%)$ with a 12-h light/dark cycle (lights on at 6 a.m.). Food and water were provided ad libitum. Animals were moved into the experiment room at least $30 \mathrm{~min}$ before the start of the tests in order for the mice to adapt to the new environment. The mice were randomly divided into control and treatment groups $(n=6-10)$.

\subsection{Drugs}

The PILAB compounds, azide, and triazoles were kindly donated by the Laboratório de Produtos Naturais e Transformações Químicas (IQ-UFRJ, Rio de Janeiro, Brazil). Acetylsalicylic acid (Sigma, Saint Louis, MO, USA), morphine, flumazenil, midazolam, and diazepam (Cristália, Itapira, Brazil) were freshly prepared in dimethyl sulfoxide (DMSO, Cristália) minutes prior to the experiments. Naloxone (Cristália), formaldehyde (Isofar, Duque de Caxias, Brazil), nor-binalthophimine, naltrindole, and CTOP and pentobarbital sodium salt (Tocris Bioscience, Minneapolis, MN, USA) were dissolved in distilled water.

\subsection{Pentobarbital-Induced Sleep Test}

The hypnotic effect of the compounds investigated was examined in a pentobarbital-induced sleep test as previously described [46]. Briefly, PILABs $(100 \mu \mathrm{mol} / \mathrm{kg})$ were administered via an intraperitoneal (i.p.) injection $10 \mathrm{~min}$ prior to the intravenous (i.v.) administration of pentobarbital sodium $(25 \mathrm{mg} / \mathrm{kg})$. Hypnosis time was considered to be the difference between the time of loss of the postural reflex and the time of its recovery. A control group received an intraperitoneal (i.p.) injection of DMSO and an i.v. injection of pentobarbital.

The time of hypnosis was further examined with the administration of vehicle and PILAB 4, 6, 7, 8, 9, 11 and $12(100 \mu \mathrm{mol} / \mathrm{kg}$ i.v. $)$ into tail of the animal. PILAB 8 was also administered 
at increasing doses to evaluate response dose in relation to hypnosis time. To investigate the mechanisms mediating the induction of hypnosis, mice were pre-treated with an i.p. injection of: flumazenil $(33 \mu \mathrm{mol} / \mathrm{kg})$, a benzodiazepine antagonist [47]; naloxone $(3.1 \mu \mathrm{mol} / \mathrm{kg})$, a non-selective opioid receptor antagonist [48]; nor-binaltorphimine $(1.5 \mu \mathrm{mol} / \mathrm{kg})$, a selective kappa opioid receptor antagonist); or naltrindole $(2.4 \mu \mathrm{mol} / \mathrm{kg})$, a selective delta opioid receptor antagonist [49]. All of these antagonists were administered 15 min prior to the administration of PILAB 8 (i.v.), except for CTOP $(0.94 \mu \mathrm{mol} / \mathrm{kg})$, a selective mu opioid receptor antagonist, which was administered $15 \mathrm{~min}$ prior to PILAB 8 [50].

\subsection{Motor Coordination (Rotarod Test)}

Dunham and Miya described a method for detecting motor harm in response to substances such as skeletal muscle relaxants or CNS depressants [51,52]. A rotarod treadmill (Insight, Model EFF 411, Ribeirão Preto, Brazil) consisting of a bar with a diameter of $2.7 \mathrm{~cm}$ and height of $40 \mathrm{~cm}$ was subdivided into four compartments by using disks $25 \mathrm{~cm}$ in diameter that rotate at 8 revolutions per minute (rpm). Male Swiss mice (20-25 g) were placed on the apparatus in three training sessions $24 \mathrm{~h}$ prior to testing as previously described [53]. The mice that could not sustain themselves on the apparatus for more than $90 \mathrm{~s}$ were excluded. Motor performance was evaluated based on the time spent walking on a rotating rod $(8 \mathrm{rpm})$ over a 3 min interval at various time points after an i.p. injection $(15,30,45,60,75$, 90 and $120 \mathrm{~min})$ of vehicle, PILAB 8 or morphine $(25 \mu \mathrm{mol} / \mathrm{kg})$.

\subsection{Anxiolytic Activity (Elevated Plus-Maze (EPM) Test)}

An LE 846 apparatus (Panlab, Barcelona, Spain) was used which contains two open arms and two closed arms connected by a central platform. Both arms are elevated to a height of $50 \mathrm{~cm}$ from the floor. An animal's position is registered by eight photoelectric cells that are arranged in each arm so that nine sectors are defined. Data were recorded with the Mazesoft- 4 Software. Male Swiss mice were treated with an i.p. injection of vehicle, PILAB $8(25 \mu \mathrm{mol} / \mathrm{kg})$, or midazolam $(6.14 \mu \mathrm{mol} / \mathrm{kg}) 10 \mathrm{~min}$ before being placed on the central platform of the maze facing an open arm. The percentage of entries into the open and closed arms, as well as the time spent in each set of arms, were counted during a 5 -min test period.

\subsection{Antinociceptive Activity Evaluation of PILAB 8}

\subsubsection{Formalin Test}

A formalin test was performed based on a protocol previously described for the quantitative study of antinociceptive effects [54]. Briefly, an intraplantar administration (i.pl.) of formalin was performed to provoke two phases of nociception behavior. The first phase ( $0-5 \mathrm{~min}$ after the injection) is referred to as the neurogenic phase. This phase is followed by a short quiescent period (5-15 $\mathrm{min})$ that precedes the second phase (15-30 min after the injection) that includes an inflammatory response. For this study, formalin $(20 \mu \mathrm{L}, 2.5 \%)$ was administered via an i.pl. injection into the right hind paw of each animal $30 \mathrm{~min}$ after an i.p. injection was made of vehicle, acetyl salicylic acid $(833 \mu \mathrm{mol} / \mathrm{kg})$, morphine $(25 \mu \mathrm{mol} / \mathrm{kg})$, or PILAB $8(25 \mu \mathrm{mol} / \mathrm{kg})$. The total time spent by each animal licking in the injected paw was then observed for $30 \mathrm{~min}$.

\subsubsection{Hot Plat Test}

Central analgesic activity was evaluated in a hot plate test. Briefly, mice were placed onto a hot plate maintained at $52 \pm 1{ }^{\circ} \mathrm{C}$ (LE 7406, Letica, Letica Scientific Instruments, Barcelona, Spain). The latency of their nociceptive threshold was recorded according to the time until licking or shaking of one of their paws or jumping was observed. Maximal permanence of the animals on the hot plate was $35 \mathrm{~s}$ to avoid damage to the paws. Animals received an i.p. injection of vehicle, PILAB $8(25 \mu \mathrm{mol} / \mathrm{kg})$, or morphine $(25 \mu \mathrm{mol} / \mathrm{kg})$. Involvement of the opioid pathway was investigated by administering 
naloxone (3.1 $\mu \mathrm{mol} / \mathrm{kg}$ i.p.) $15 \mathrm{~min}$ prior to the administration of PILAB 8. Antinociceptive activity $(\mathrm{AA} \%)$ was calculated using Equation (1):

$$
\% \mathrm{AA}=(\text { postdrug latency })-(\text { predrug latency }) \times 100 \%(35 \mathrm{~s})-(\text { predrug latency })
$$

\subsection{Statistical Analysis}

Data are expressed as the mean \pm standard error of the mean (SEM) and were analyzed using one-way analysis of variance (ANOVA) followed by Dunnett's multiple comparison test. GraphPad Prism, version 6.0 (GraphPad Software Inc., San Diego, CA, USA), was used to perform the statistical analyses and differences with a $p>0.05$ were considered significant.

\section{Conclusions}

In conclusion, the results of the present study provide evidence that the triazole scaffold potentiates the activity of isatin ketals and an apolar substituent attached to this ring increases the effects on the CNS. PILAB 8, bearing the longest alkyl chain among the tested compounds, showed the best hypnotic profile. This compound was selected for subsequent experiments, indicating that can activate $\mu$-opioid receptors to provoke antinociceptive effect without morphine-like side effects. In addition, PILAB 8 was found to effectively reverse anxiety independent of a pain response.

Supplementary Materials: Supplementary materials are available online.

Acknowledgments: This work was supported in part by grants from the Conselho Nacional de Desenvolvimento Cientifico e Tecnológico (CNPq), Coordenação de Aperfeiçoamento de Pessoal de Nível Superior (CAPES), Programa de Apoio a Núcleos de Experiência (PRONEX), Fundação Carlos Chagas Filho de Amparo à Pesquisa do Estado do Rio de Janeiro (FAPERJ), Instituto Nacional de Ciência e Tecnologia-Fármacos e Medicamentos (INCT-INOFAR).

Author Contributions: G.Z.-S., R.T.S. and B.V.d.S. designed the research study; G.C.M. and B.R. performed pharmacological experiments; A.d.C.P., B.N.M.d.S., V.F.F. and F.d.C.d.S. responsible for the design and synthesis of substances; G.C.M., R.T.S., G.Z.-S. and B.V.d.S analyzed the data.

Conflicts of Interest: The authors declare no conflict of interest.

\section{References}

1. Castana, O.; Anagiotos, G.; Rempelos, G.; Adalopoulou, A.; Kokkinakis, C.; Giannakidou, M.; Diplas, D.B.; Alexakis, D. Pain response and pain control in burn patients. Ann. Burns Fire Disasters 2009, 22, 88-89. [PubMed]

2. Woolf, C.J.; Mannion, R.J. Neuropathic pain: Aetiology, symptoms, mechanisms, and management. Lancet 1999, 353, 1959-1964. [CrossRef]

3. Ossipov, M.H.; Dussor, G.O.; Porreca, F. Central modulation of pain. J. Clin. Investig. 2010, 120, 3779-3787. [CrossRef] [PubMed]

4. Williams, A.C.; Craig, K.D. Updating the definition of pain. Pain 2016, 157, 2420-2423. [CrossRef] [PubMed]

5. Pain terms: A list with definitions and notes on usage. Recommended by the IASP Subcommittee on Taxonomy. Pain 1979, 6, 249.

6. Jirkof, P. Side effects of pain and analgesia in animal experimentation. Lab Anim. (NY) 2017, 46, 123-128. [CrossRef] [PubMed]

7. Wolkerstorfer, A.; Handler, N.; Buschmann, H. New approaches to treating pain. Bioorg. Med. Chem. Lett. 2016, 26, 1103-1119. [CrossRef] [PubMed]

8. Barrett, J.E.; Haas, D.A. Perspectives and Trends in Pharmacological Approaches to the Modulation of Pain. Adv. Pharmacol. 2016, 75, 1-33. [PubMed]

9. Kuner, R.; Flor, H. Structural plasticity and reorganisation in chronic pain. Nat. Rev. Neurosci. 2016, 18, 20-30. [CrossRef] [PubMed]

10. Silva, J.F.M.; Garden, S.J.; Pinto, A.C. The chemistry of isatins: A review from 1975 to 1999. J. Braz. Chem. Soc. 2001, 12, 273-324. [CrossRef]

11. Silva, B.V. Isatin, a versatile molecule: Studies in Brazil. J. Braz. Chem. Soc. 2013, 24, 707-720. [CrossRef] 
12. Armando, I.; Glover, V.; Sandler, M. Distribution of endogenous benzodiazepine receptor ligand-monoamine oxidase inhibitory activity (tribulin) in tissues. Life Sci. 1986, 38, 2063-2067. [CrossRef]

13. Yuwiler, A. The effect of isatin (tribulin) on metabolism of indoles in the rat brain and pineal: In vitro and in vivo studies. Neurochem. Res. 1990, 15, 95-100. [CrossRef] [PubMed]

14. Prakash, C.R.; Raja, S.; Saravanan, G. Synthesis, characterization and anticonvulsant activity of novel Schiff base of isatin derivatives. Int. J. Pharm. Pharm. Sci. 2010, 2, 177-181.

15. Damgaard, M.; Al-Khawaja, A.; Vogensen, S.B.; Jurik, A.; Sijm, M.; Lie, M.E.; Baek, M.I.; Rosenthal, E.; Jensen, A.A.; Ecker, G.F.; et al. Identification of the First Highly Subtype-Selective Inhibitor of Human GABA Transporter GAT3. ACS Chem. Neurosci. 2015, 6, 1591-1599. [CrossRef] [PubMed]

16. Poslusney, M.S.; Melancon, B.J.; Gentry, P.R.; Sheffler, D.J.; Bridges, T.M.; Utley, T.J.; Daniels, J.S.; Niswender, C.M.; Conn, P.J.; Lindsley, C.W.; et al. Spirocyclic replacements for the isatin in the highly selective, muscarinic M1 PAM ML137: The continued optimization of an MLPCN probe molecule. Bioorg. Med. Chem. Lett. 2013, 23, 1860-1864. [CrossRef] [PubMed]

17. Phillips, O.A.; Sharaf, L.H.; D'Silva, R.; Udo, E.E.; Benov, L. Evaluation of the monoamine oxidases inhibitory activity of a small series of 5-(azole)methyl oxazolidinones. Eur. J. Pharm. Sci. 2015, 71, 56-61. [CrossRef] [PubMed]

18. Akrami, H.; Mirjalili, B.F.; Khoobi, M.; Moradi, A.; Nadri, H.; Emami, S.; Foroumadi, A.; Vosooghi, M.; Shafiee, A. 9H-Carbazole Derivatives Containing the N-Benzyl-1,2,3-triazole Moiety as New Acetylcholinesterase Inhibitors. Arch. Pharm. (Weinh.) 2015, 348, 366-374. [CrossRef] [PubMed]

19. Zapata-Sudo, G.; Pontes, L.B.; Gabriel, D.; Mendes, T.C.; Ribeiro, N.M.; Pinto, A.C.; Trachez, M.M.; Sudo, R.T. Sedative-hypnotic profile of novel isatin ketals. Pharmacol. Biochem. Behav. 2007, 86, 678-685. [CrossRef] [PubMed]

20. Silva, B.N.M.; Silva, B.V.S.; Silva, F.C.; Gonzaga, D.T.G.; Ferreira, V.F.; Pinto, A.C. Synthesis of Novel Isatin-Type 5'-(4-Alkyl/Aryl-1H-1,2,3-triazoles) via 1,3-Dipolar Cycloaddition Reactions. J. Braz. Chem. Soc. 2013, 24, 179-183. [CrossRef]

21. Silva, B.N.M.; Pinto, A.C.; Silva, F.C.; Ferreira, V.F.; Silva, B.V. Ultrasound-Assisted Synthesis of Isatin-Type 5'-(4-Alkyl/Aryl-1H-1,2,3-triazoles) via 1,3-Dipolar Cycloaddition Reactions. J. Braz. Chem. Soc. 2016, 27, 2378-2382. [CrossRef]

22. Iwaszkiewicz, K.S.; Schneider, J.J.; Hua, S. Targeting peripheral opioid receptors to promote analgesic and anti-inflammatory actions. Front. Pharmacol. 2013, 4, 132. [CrossRef] [PubMed]

23. Bessa, J.M.; Oliveira, M.; Cerqueira, J.J.; Almeida, O.F.; Sousa, N. Age-related qualitative shift in emotional behaviour: Paradoxical findings after re-exposure of rats in the elevated-plus maze. Behav. Brain Res. 2005, 162, 135-142. [CrossRef] [PubMed]

24. Lister, R.G. The use of a plus-maze to measure anxiety in the mouse. Psychopharmacology (Berl.) 1987, 92, 180-185. [CrossRef]

25. Lister, R.G. Ethologically-based animal models of anxiety disorders. Pharmacol. Ther. 1990, 46, 321-340. [CrossRef]

26. Pellow, S.; File, S.E. Anxiolytic and anxiogenic drug effects on exploratory activity in an elevated plus-maze: A novel test of anxiety in the rat. Pharmacol. Biochem. Behav. 1986, 24, 525-529. [CrossRef]

27. Mora, S.; Diaz-Veliz, G.; Millan, R.; Lungenstrass, H.; Quiros, S.; Coto-Morales, T.; Hellion-Ibarrola, M.C. Anxiolytic and antidepressant-like effects of the hydroalcoholic extract from Aloysia polystachya in rats. Pharmacol. Biochem. Behav. 2005, 82, 373-378. [CrossRef] [PubMed]

28. Noori Ahmad Abadi, M.; Mortazavi, M.; Kalani, N.; Zare Marzouni, H.; Kooti, W.; Ali-Akbari, S. Effect of Hydroalcoholic Extract of Rosmarinus officinalis L. Leaf on Anxiety in Mice. J. Evid. Based Complement. Altern. Med. 2016, 21, NP85-NP90. [CrossRef] [PubMed]

29. Colasanti, A.; Rabiner, E.A.; Lingford-Hughes, A.; Nutt, D.J. Opioids and anxiety. J. Psychopharmacol. 2011, 25, 1415-1433. [CrossRef] [PubMed]

30. Asakawa, A.; Inui, A.; Momose, K.; Ueno, N.; Fujino, M.A.; Kasuga, M. Endomorphins have orexigenic and anxiolytic activities in mice. Neuroreport 1998, 9, 2265-2267. [CrossRef] [PubMed]

31. Wang, K.C.; Lee, Y.J.; Fan, L.W.; Yang, P.P.; Tao, P.L.; Ho, I.K.; Tien, L.T. Mu-opioid receptor knockout mice are more sensitive to chlordiazepoxide-induced anxiolytic behavior. Brain Res. Bull. 2013, 90, 137-141. [CrossRef] [PubMed] 
32. Lv, D.; Wang, X.; Dong, J.; Zhuang, Y.; Huang, S.; Ma, B.; Chen, P.; Li, X.; Zhang, B.; Li, Z.; et al. Systematic characterization of lncRNAs' cell-to-cell expression heterogeneity in glioblastoma cells. Oncotarget 2016, 7, 18403-18414. [CrossRef] [PubMed]

33. Le Bars, D.; Gozariu, M.; Cadden, S.W. Animal models of nociception. Pharmacol. Rev. 2001, 53, 597-652. [PubMed]

34. Hunskaar, S.; Hole, K. The formalin test in mice: Dissociation between inflammatory and non-inflammatory pain. Pain 1987, 30, 103-114. [CrossRef]

35. Mendes, T.C.; Raimundo, J.M.; Nascimento-Junior, N.M.; Fraga, C.A.; Barreiro, E.J.; Sudo, R.T.; Zapata-Sudo, G. Sedation and antinociception induced by a new pyrazolo[3,4- $b]$ pyrrolo[3,4- $d]$ pyridine derivative (LASSBio-873) is modulated by activation of muscarinic receptors. Pharmacol. Biochem. Behav. 2009, 94, 70-74. [CrossRef] [PubMed]

36. De Queiroz, R.B.; de Carvalho, F.L.; Fonseca, D.V.; Barbosa-Filho, J.M.; Salgado, P.R.; Paulo, L.L.; de Queiroz, A.B.; Pordeus, L.C.; de Souza, S.A.; Souza, H.D.; et al. Antinociceptive effect of hydantoin 3-phenyl-5-(4-ethylphenyl)-imidazolidine-2,4-dione in mice. Molecules 2015, 20, 974-986. [CrossRef] [PubMed]

37. Fongang, A.L.; Laure Nguemfo, E.; Djouatsa Nangue, Y.; Bogning Zangueu, C.; Fouokeng, Y.; Azebaze, A.G.; Jose Llorent-Martinez, E.; Cordova, M.L.; Bertrand Dongmo, A.; Vierling, W. Antinociceptive and anti-inflammatory effects of the methanolic stem bark extract of Antrocaryon klaineanum Pierre (Anacardiaceae) in mice and rats. J. Ethnopharmacol. 2017, 203, 11-19. [CrossRef] [PubMed]

38. Coderre, T.J.; Vaccarino, A.L.; Melzack, R. Central nervous system plasticity in the tonic pain response to subcutaneous formalin injection. Brain Res. 1990, 535, 155-158. [CrossRef]

39. Dos Anjos, K.S.; Araujo-Filho, H.G.; Duarte, M.C.; Costa, V.C.; Tavares, J.F.; Silva, M.S.; Almeida, J.R.; Souza, N.A.; Rolim, L.A.; Menezes, I.R.; et al. HPLC-DAD analysis, antinociceptive and anti-inflammatory properties of the ethanolic extract of Hyptis umbrosa in mice. EXCLI J. 2017, 16, 14-24. [PubMed]

40. Shibata, M.; Ohkubo, T.; Takahashi, H.; Inoki, R. Modified formalin test: Characteristic biphasic pain response. Pain 1989, 38, 347-352. [CrossRef]

41. Al-Ghamdi, M.S. The anti-inflammatory, analgesic and antipyretic activity of Nigella sativa. J. Ethnopharmacol. 2001, 76, 45-48. [CrossRef]

42. Giorno, T.B.; Ballard, Y.L.; Cordeiro, M.S.; Silva, B.V.; Pinto, A.C.; Fernandes, P.D. Central and peripheral antinociceptive activity of 3-(2-oxopropyl)-3-hydroxy-2-oxindoles. Pharmacol. Biochem. Behav. 2015, 135, 13-19. [CrossRef] [PubMed]

43. Stein, C. Targeting pain and inflammation by peripherally acting opioids. Front. Pharmacol. 2013, 4, 123. [CrossRef] [PubMed]

44. Stein, C.; Baerwald, C. Opioids for the treatment of arthritis pain. Expert Opin. Pharmacother. 2014, 15, 193-202. [CrossRef] [PubMed]

45. Stein, C. The control of pain in peripheral tissue by opioids. N. Engl. J. Med. 1995, 332, 1685-1690. [PubMed]

46. Menegatti, R.; Silva, G.M.; Zapata-Sudo, G.; Raimundo, J.M.; Sudo, R.T.; Barreiro, E.J.; Fraga, C.A. Design, synthesis, and pharmacological evaluation of new neuroactive pyrazolo[3,4- $b]$ pyrrolo[3,4- $d$ ]pyridine derivatives with in vivo hypnotic and analgesic profile. Bioorg. Med. Chem. 2006, 14, 632-640. [CrossRef] [PubMed]

47. Savic, M.M.; Obradovic, D.I.; Ugresic, N.D.; Cook, J.M.; Yin, W.; Bokonjic, D.R. Bidirectional effects of benzodiazepine binding site ligands in the elevated plus-maze: Differential antagonism by flumazenil and beta-CCt. Pharmacol. Biochem. Behav. 2004, 79, 279-290. [CrossRef] [PubMed]

48. Zomkowski, A.D.; Santos, A.R.; Rodrigues, A.L. Evidence for the involvement of the opioid system in the agmatine antidepressant-like effect in the forced swimming test. Neurosci. Lett. 2005, 381, 279-283. [CrossRef] [PubMed]

49. Demir Ozkay, U.; Can, O.D. Anti-nociceptive effect of vitexin mediated by the opioid system in mice. Pharmacol. Biochem. Behav. 2013, 109, 23-30. [CrossRef] [PubMed]

50. Lesscher, H.M.; Hordijk, M.; Bondar, N.P.; Alekseyenko, O.V.; Burbach, J.P.; van Ree, J.M.; Gerrits, M.A. $\mathrm{Mu}$-opioid receptors are not involved in acute cocaine-induced locomotor activity nor in development of cocaine-induced behavioral sensitization in mice. Neuropsychopharmacology 2005, 30, 278-285. [CrossRef] [PubMed] 
51. Pultrini Ade, M.; Galindo, L.A.; Costa, M. Effects of the essential oil from Citrus aurantium L. in experimental anxiety models in mice. Life Sci. 2006, 78, 1720-1725. [CrossRef] [PubMed]

52. Dunham, N.W.; Miya, T.S. A note on a simple apparatus for detecting neurological deficit in rats and mice. J. Am. Pharm. Assoc. Am. Pharm. Assoc. 1957, 46, 208-209. [CrossRef] [PubMed]

53. Souto-Maior, F.N.; de Carvalho, F.L.; de Morais, L.C.; Netto, S.M.; de Sousa, D.P.; de Almeida, R.N. Anxiolytic-like effects of inhaled linalool oxide in experimental mouse anxiety models. Pharmacol. Biochem. Behav. 2011, 100, 259-263. [CrossRef] [PubMed]

54. Dubuisson, D.; Dennis, S.G. The formalin test: A quantitative study of the analgesic effects of morphine, meperidine, and brain stem stimulation in rats and cats. Pain 1977, 4, 161-174. [CrossRef]

Sample Availability: Not Available.

(C) 2017 by the authors. Licensee MDPI, Basel, Switzerland. This article is an open access article distributed under the terms and conditions of the Creative Commons Attribution (CC BY) license (http://creativecommons.org/licenses/by/4.0/). 